\title{
Legestudiets skjulte læring - det bøkene ikke forteller
}

\author{
I møte med pasientskjebner opplever medisinstudenter ofte både faglig og menneskelig utilstrekkelighet. \\ Mange velger å distansere seg følelsesmessig i en misforstått «profesjonalitet». Det blir for ubehagelig \\ å nærme seg pasientens perspektiv. Men hva er medisinsk profesjonalitet?
}

\author{
Lars Eivind Kvarstein \\ lekvarstein@gmail.com \\ Edvin Schei
}

Teksten er basert på en særoppgave på profesjonsstudiet i medisin ved Universitetet i Bergen våren 2014, veiledet av Edvin Schei: Kvarstein, L. Legestudiets skjulte læring - det bøkene ikke forteller. Det medisinsk-odontologiske fakultet, UiB, 2014.

En ung medisinstudent uttrykte seg slik: «Etter en lang samtale grep pasienten tak i meg og gav meg en klem, mens hun gråtkvalt takket meg for at jeg var der. Skremt av nærheten, fór jeg ut av rommet. Det ble for nært!» (1).

Mange starter som engasjerte, sultne og nysgjerrige førsteårsstudenter, men glir sakte inn i flokken av hvitkledde leger som beveger seg hastig gjennom sykehuskorridorene, tilsynelatende uberørte og "profesjonelle». Å være uberørt av pasientens lidelse er imidlertid ikke det samme som «medisinsk profesjonalitet». Pasientene etterspør kompetanse i empati og kommunikasjon sammen med evne til operasjonelle beslutninger og tekniske ferdigheter. Det er derfor en alvorlig kritikk når nyutdannede leger oppleves som kjølige og distanserte $(2,3)$. Er det noe galt med dagens medisinstudium? I trivselsunders økelsen utført ved medisinsk fakultet ved Universitetet i Bergen svarte $84 \%$ av 586 studenter at de savnet mer faglig oppfølging og personlig tilbakemelding i løpet av studiet (4). Kontakten mellom student og lege blir lett begrenset til hastige, informative instrukser på avdelingene eller operasjonsstua, og i auditoriet oppnår man sjelden den gode lærer-svenn-relasjonen.

\section{Medisinsk profesjonalitet}

Med økende krav til effektivitet i helsevesenet har legen kommet i klem mellom økonomiske interesser og de tradisjonelle medisinske kjerneverdier. Fagmiljøene ved nordamerikanske og kanadiske universiteter opplevde i 1990-årene at fokuse- ringen på effektivitet førte til en forvitring av legerollen (5). De så behov for økt oppmerksomhet på profesjonalitetsbegrepet og stilte krav om reetablering av tradisjonelle, humanistiske verdier i den medisinske profesjonen. Men at leger videre forventes å ha en høyere etisk standard enn folk flest, er ikke uproblematisk (6), da en slik holdning snarere kan være med på å opprettholde en overdreven tro på egen betydning.

\section{Definisjon av profesjonalitet}

$\AA$ definere «medisinsk profesjonalitet» er å bestemme hva som skal være kjernen i legerollen. Mangel på faglig diskusjon av profesjonalitetsbegrepet skaper rom for en dårlig gjennomtenkt oppfatning av faglig kvalitet. Det er fortsatt de som mener at leger kan være unntatt krav til god menneskekontakt så lenge de er teknisk dyktige. Det skapes dermed en implisitt forståelse av at begrepet profesjonell betegner de mer tekniske aspektene ved medisinsk utdanning. Men tekniske ferdigheter må alltid anvendes med et formål, og formålet bestemmes av pasientens situasjon, person og livsmål. Legens profesjonalitet omfatter derfor både teknisk kunnskap, praktiske ferdigheter og menneskelige hjelperegenskaper.

David T. Stern presenterer en modell der medisinsk profesjonalitet bæres av fire grunnsøyler: fremragende praksis, humanisme, etterrettelighet og altruisme (7) (fig 1). Søylene hviler på en sokkel av klinisk kompetanse og kommunikasjonsferdigheter, samt etisk og juridisk forståelse.

Man kan hevde at modellen opererer med en utopisk standard som ingen leger kan leve opp til, men den tjener som en målsetting og gir en grunnleggende forståelse av elementene i medisinsk profesjonalitet. Altruisme kan i Sterns modell også tas med i hver av de tre andre søylene og blir slik sett et kjerneelement i god profesjonsutøvelse (8).

\section{Status presens}

Flere studier har vist stagnasjon og tilbakegang i medisinstudenters moralske utvikling i løpet av studiet, og mindre progresjon av moralsk modenhet blant medisinstuden- ter sammenliknet med kolleger i andre fagfelt (9). Det er grunn til å spørre seg om det hektiske arbeidsmiljøet i sykehusene bryter ned idealistiske holdninger blant medisinstudenter (10). Majoriteten av medisinstudentene ved seks av fakultetene i Pennsylvania i USA opplevde at deres egne moralske verdier og kommunikasjonsevner gradvis forvitret i løpet av den kliniske delen av studiet (11).

Filosofen Arne Johan Vetlesen stiller kritisk spørsmål om hvorvidt medisinstudiet med sin konkurransementalitet forbereder studenter godt nok til legegjerningen. «Så lenge legeutdanningen fungerer som en seksårig innøvelse i en vellykkethetens habitus med flinkhet og ufeilbarlighet som fremste dyder, vil utdanningen til lege stå i fare for å være den verste fiende til praksisen som lege» (12).

\section{Hvordan læres profesjonalitet?}

Stern argumenterer for at de personlige elementene i profesjonalitetsbegrepet kan læres, fordi mennesker utvikler sin karakter og sin moralske dømmekraft gjennom erfaringer (7). Men det er fortsatt et spørsmål om endringer $i$ undervisning og studieplan er tilstrekkelig for å oppnå endring.

Norske fakulteter har forsøkt å styrke temaet profesjonalitet i studentundervisningen. Ved Universitetet i Bergen har imidlertid fokuset på altruisme og de pasientsentrerte idealene $\mathrm{i}$ all vesentlighet blitt formidlet av et mindre antall forelesere. Vårt inntrykk er at mer biomedisinsk orienterte forelesere tidvis neglisjerer dette både i forelesninger og i klinisk undervisning. Det er beskrevet hvordan inkongruens mellom fagets teori og rollemodellers praksis skaper konflikt i læringsprosessen. Diskrepans mellom det man hører lærerne si og det man ser dem gjøre, kan bli en kilde til kynisme blant studenter (13). Forelesninger og spredte kurs vil ikke være tilstrekkelig for å oppnå en internalisering av profesjonalitet og en oppøving av tilhørende atferd. Kun en fraksjon av medisinsk kultur formidles gjennom timeplanaktivitet. Hovedvekten av verdier, holdninger og oppførsel formidles utenom den formelle læringen, gjennom 
såkalt skjult læring (14). Det som trengs, er derfor bevisste holdningsendringer og endret praksis innad i institusjonene der studentene oppholder seg.

\section{Rollemodeller}

Medisinstudenten tar til seg holdningssett fra erfarne klinikere gjennom å observere kroppsspråk, talemåter og holdninger. $\AA$ treffe på en god lege i studiet kan ha stor betydning. Organiseringen av studiet synes ikke å ha tatt dette innover seg. Formidling av verdier og holdninger skjer hovedsakelig gjennom rollemodellenes opptreden i klinisk praksis og i møte med studenter. Det er en utfordring for utdanningsinstitusjonene å skape bevissthet gjennom hele systemet om den store påvirkningskraften leger har på studenter. For å sette denne påvirkningskraften i arbeid bør man se etter muligheter for å utvikle gode systemer for samspill mellom leger og studenter.

\section{Veiledningsgrupper}

Essensen i gode læringsmiljøer og relasjoner der kunnskap utveksles, karakteriseres av tillit mellom studenter og laerere, og tillit som er bygd opp over tid med en viss varighet av student-loerer-kontakten. Ifølge Brodal er mangel på kontinuitet et hovedproblem ved dagens medisinstudier (15). Stern \& Papadakis hevder at formidling av profesjonalitet skjer best ved en kombinasjon av læring via rollemodeller og refleksjon i smågrupper (16). Refleksjon hjelper studenter til å bli bevisst på hvilken smeltedigel de faktisk befinner seg i. Det kan forhindre fremvekst av ureflektert avstumpethet og kynisme. Dialog i smågrupper kan ikke direkte sammenliknes med en forelesningssituasjon (1). Læring uten refleksjon kan føre til stagnasjon av studentenes modningsprosesser, mens aktiv smågruppelæring om pasient-lege-kommunikasjon kan skape positive holdningsendringer (2).

Det finnes læringsformer som bidrar til vekst i studenters evne til moralsk skjønn, og som kan anvendes i veiledningsgrupper i medisinstudiet (17).

En student sa det slik: «Jeg er helt sikker på at studenters møter med «de ordentlige legene» er av enorm betydning! Jeg tror ikke problemet for oss studenter ligger i at leger vi møter, ikke er ålreite, men at vi ikke treffes igjen.»

Empatitapet og kynismen som beskrives blant medisinstudenter, må i større grad tas på alvor. Kontinuiteten i student-lege-relasjonene bør styrkes for å unngå emosjonell distansering. Tillit, trygghet og identitetsbygging skjer over tid og krever at relasjonen mellom student og lege er av en viss varighet.

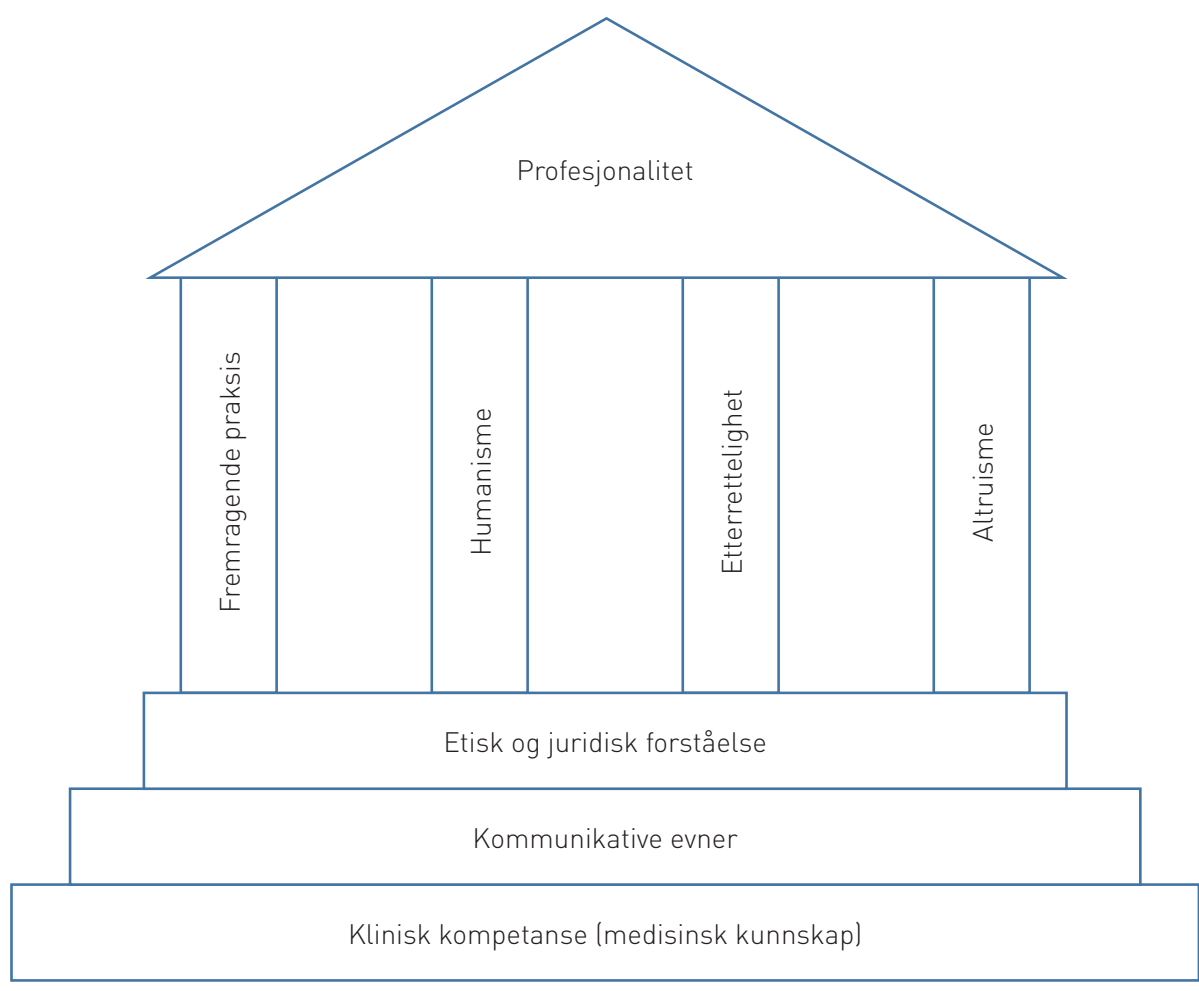

Figur 1 I Sterns modell bæres medisinsk profesjonalitet av fire grunnsøyler: fremragende praksis, humanisme, etterrettelighet og altruisme

Det er behov for arenaer der det settes fokus på utvikling av profesjonsidentitet et sted der studenten får mulighet til å skape relasjoner til eldre leger og gis tid og rom til refleksjon over rollen som lege og legestudent.

\section{Lars Eivind Kvarstein (f. 1989)}

er medisinstudent ved Universitetet i Bergen. Forfatter har fylt ut ICMJE-skjemaet og oppgir ingen interessekonflikter.

\section{Edvin Schei (f. 1957)}

er professor ved Universitetet i Bergen og leder av profesjonalitetskomiteen ved det medisinskodontologiske fakultet, fastlege og leder av Filosofisk poliklinikk. Han har skrevet boken Hva er medisin? (2007).

Forfatter har fylt ut ICMJE-skjemaet og oppgir ingen interessekonflikter.

\section{Litteratur}

1. Kvarstein L. Legestudiets skjulte læring - det bøkene ikke forteller. Særoppgave på profesjonsstudiet i medisin. Bergen: Det medisinsk-odontologiske fakultet, Universitetet i Bergen, 2014.

2. Branch WT Jr. Supporting the moral development of medical students. J Gen Intern Med 2000; 15 . $503-8$.

3. Ingelfinger FJ. Arrogance. N Engl J Med 1980; 303: 1507-11

4. Trivselsundersøkelse blant medisinstudenter ved Det medisinsk-odontologiske fakultet, UiB, 2012. Rapport. Bergen: Mental helse-gruppen under Medisinsk fagutvalg ved UiB.
5 . www med uottawa.ca/students/md/ professionalism/eng/emergence_professionalism. html (18.6.2013).

6. Aasland OG. Legerollen-fra pidestall til skammel. Tidsskr Nor Lægeforen 2006: 126: 61-2.

7. Stern DT. Measuring medical professionalism. New York/Oxford: Oxford University Press, 2006.

8. Baerheim A. Medisinsk profesjonalitet. Tidsskr Nor Lægeforen 2007: 127: 2074

9. Self D.B., D. Moral Reasoning in Medicine.

10. Mizrahi T. Getting rid of patients: contradictions in the socialisation of internists to the doctor-patien relationship. Sociol Health IIln 1985; 7: 214-35.

11. Feudtner C, Christakis DA, Christakis NA. Do clinical clerks suffer ethical erosion? Students' perceptions of their ethical environment and personal development. Acad Med 1994; 69: 670-9

12. Vetlesen AJ. Profesjonell og personlig? Legerollen mellom vellykkethet og sårbarhet. Tidsskr Nor Lægeforen 2001; 121: 1118-21.

13. Coulehan J. Viewpoint: today's professionalism: engaging the mind but not the heart. Acad Med 2005; 80: 892-8.

14. Hafferty FW, Franks R. The hidden curriculum, ethics teaching, and the structure of medical education. Acad Med 1994; 69: 861-71.

15. Brodal P. Et varselrop om læringsmiljøet i klinikken. Tidsskr Nor Legeforen 2012: 132: 698 .

16. Stern DT, Papadakis M. The developing physician-becoming a professional. N Engl J Med 2006 355: 1794-9.

17. Self DJ, Olivarez M, Baldwin DC Jr. The amount of small-group case-study discussion needed to improve moral reasoning skills of medical students. Acad Med 1998; 73: $521-3$.

Mottatt 2.5. 2014 og godkjent 29.5. 2014. Redaktør: Hanne Støre Valeur.

Podkast på www.tidsskriftet.no 